\title{
Disturbed spermatogenic signaling in pituitary adenylate cyclase activating polypeptide-deficient mice
}

\author{
D Reglodi ${ }^{1}$, S Cseh², B Somoskoi², B D Fulop ${ }^{1}$, E Szentleleky ${ }^{3}$, V Szegeczki ${ }^{3}$, A Kovacs ${ }^{1}$,

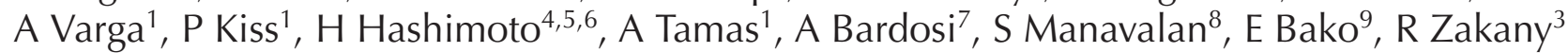 \\ and T Juhasz ${ }^{3}$
}

\begin{abstract}
${ }^{1}$ Department of Anatomy, MTA-PTE PACAP Research Team, Centre for Neuroscience, University of Pecs, Pecs, Hungary, ${ }^{2}$ Department and Clinic of Reproduction, University of Veterinary Medicine, Budapest, Hungary, ${ }^{3}$ Department of Anatomy, Histology and Embryology, Faculty of Medicine, University of Debrecen, Debrecen, Hungary, ${ }^{4}$ Laboratory of Molecular Neuropharmacology, Graduate School of Pharmaceutical Sciences, Osaka University, Suita, Osaka, Japan, ${ }^{5}$ Molecular Research Center for Children's Mental Development, United Graduate School of Child Development, Osaka University, Kanazawa University, Hamamatsu University School of Medicine, Chiba University and University of Fukui, Suita, Osaka, Japan, ${ }^{6}$ Division of Bioscience, Institute for Datability Science, Osaka University, Suita, Osaka, Japan, ${ }^{7}$ MVZ für Histologie, Zytologie und Molekulare Diagnostik, Trier, Germany, ${ }^{8}$ Department of Basic Sciences, National University of Health Sciences, Pinellas Park, Florida, USA and ${ }^{9}$ Cell Biology and Signalling Research Group of the Hungarian Academy of Sciences, Department of Medical Chemistry, Research Centre for Molecular Medicine, Faculty of Medicine, University of Debrecen, Debrecen, Hungary
\end{abstract}

Correspondence should be addressed to D Reglodi: dora.reglodi@aok.pte.hu

\begin{abstract}
PACAP is a neuropeptide with diverse functions in various organs, including reproductive system. It is present in the testis in high concentrations, and in addition to the stage-specific expression within the seminiferous tubules, PACAP affects spermatogenesis and the functions of Leydig and Sertoli cells. Mice lacking endogenous PACAP show reduced fertility, but the possibility of abnormalities in spermatogenic signaling has not yet been investigated. Therefore, we performed a detailed morphological analysis of spermatozoa, sperm motility and investigated signaling pathways that play a role during spermatogenesis in knockout mice. No significant alterations were found in testicular morphology or motility of sperm in homozygous and heterozygous PACAP-deficient mice in spite of the moderately increased number of severely damaged sperms. However, we found robust changes in mRNA and/or protein expression of several factors that play an important role in spermatogenesis. Protein kinase A expression was markedly reduced, while downstream phospho-ERK and p38 were elevated in knockout animals. Expression of major transcription factors, such as Sox9 and phospho-Sox9, was decreased, while that of Sox10, as a redundant factor, was increased in PACAP-deficient mice. The reduced phospho-Sox9 expression was partly due to increased expression and activity of phosphatase PP2A in knockout mice. Targets of Sox transcription factors, such as collagen type IV, were reduced in knockout mice. In summary, our results show that lack of PACAP leads to disturbed signaling in spermatogenesis, which could be a factor responsible for reduced fertility in PACAP knockout mice, and further support the role of PACAP in reproduction.

Reproduction (2018) 155 127-137
\end{abstract}

\section{Introduction}

Pituitary adenylate cyclase activating polypeptide (PACAP) was originally isolated as a hypothalamic neuropeptide that stimulates adenylate cyclase activity, and thus, the release of several hormones in the pituitary (Miyata et al. 1989). PACAP plays diverse roles in the endocrine system, including the gonadal axis (Counis et al. 2007, Vaudry et al. 2009, Koves et al. 2014, 2016, Bardosi et al. 2016, Egri et al. 2016).
The modulatory effects on gonadotropin secretion suggest a role for PACAP in reproduction (Sherwood et al. 2000, Apostolakis et al. 2005, Kanasaki et al. 2016). An important discovery regarding male reproductive system came soon after the isolation of PACAP, showing that the peptide can be found in the testis in high concentrations, similar in range to those in the CNS (Arimura et al. 1991). The high levels of PACAP in the testis suggest that it plays an important role in spermatogenesis and/or sperm functions 
(Daniel et al. 2000, Li et al. 2000, Li \& Arimura 2003). Indeed, PACAP has been shown to influence the development and functioning of spermatozoa (Gozes et al. 1998, Koh et al. 2003, 2006, Li et al. 2004). PACAP expression was found mainly in immature and, to a smaller extent, in mature sperms (Hannibal \& Fahrenkrug 1995). PACAP regulates the activity of the supporting Sertoli cells, and acts at the hormonal level influencing the synthesis of testosterone by Leydig cells. Epididymis-derived PACAP may also influence the final stages of spermiogenesis (Heindel et al. 1992, Shioda et al. 1994, West et al. 1995, Csaba et al. 1997, Rossato et al. 1997, Yanaihara et al. 1998, El-Gehani et al. 2000, Li et al. 2004, Lacombe et al. 2006, Matsumoto et al. 2008, Tanii et al. 2011).

In mature sperms of golden hamster, it has been found that the addition of $\mathrm{PACAP}_{7-27}$ hybrid antagonist results in a reduction in motility, implying the stimulatory effect of PACAP on sperm motility (Gozes et al. 1998). Indeed, PACAP has been reported to increase motility and penetration of ovum to promote fertilization in mice (Tanii et al. 2011). In an earlier study, we had confirmed this hypothesis in human sperms: we found that PACAP stimulated the slowly moving population, while it did not influence the cells with normal motility (Brubel et al. 2012). Furthermore, PACAP has been shown to regulate the synthesis of both secreted and intracellular proteins of spermatids and spermatocytes in vitro (West et al. 1995).

Mice deficient in PACAP are known to have several abnormalities during development (Reglodi et al. 2012, Nemeth et al. 2014, Sandor et al. 2016), and they also display reduced fertility (Sherwood et al. 2007, Reglodi et al. 2012). This is not limited to just one factor being abnormally altered, but it seems that the reproduction of these animals is affected at several levels. PACAPdeficient mice have been described to have impaired implantation (Isaac \& Sherwood 2008), which, together with the increased rate of early postnatal death also leads to a reduced number of offspring (Gray et al. 2001, Wilson \& Cumming 2008). As PACAP is involved in several other processes, such as gametogenesis (Apa et al. 2002, Li et al. 2004, Barberi et al. 2007, Koppan et al. 2012, Canipari et al. 2016), placental development (Horvath et al. 2014, 2016) and gonadotropin regulation (Kanasaki et al. 2016), it can be hypothesized that lack of PACAP may also influence reproduction in germ cells (Lacombe et al. 2006). In a previous study, we found that the diameter of sperm heads in PACAP-deficient mice was smaller, (Brubel et al. 2012), but no data were obtained as to whether this resulted in abnormal motility. Therefore, the aim of the present study was to perform detailed morphological analysis of spermatozoa, sperm motility and to investigate signaling pathways playing a role during spermatogenesis in order to elucidate the role of endogenous PACAP at the molecular level.

\section{Materials and methods}

\section{Animals and genotyping protocol}

Generation of male PACAP-deficient mice on CD-1 background was described earlier, and it was demonstrated that heterozygous mice show a $\sim 70 \%$ reduction of PACAP level (Hashimoto et al. 2001). Three-month-old wild-type (WT), heterozygous (HZ) and homozygous knockout (KO) mice were kept under light/darkness cycles of 12/12 h with free access to food and water. The study was carried out in accordance with ethical guidelines (ethical permission number for this study: BA02/2000-15024/2011, University of Pecs, Hungary). Genotyping was performed using Phire Animal Tissue Direct PCR Kit (Thermo Fischer Scientific) according to the manufacturer's instructions. Primer sequences used for the detection of wild-type and KO DNA signatures of PACAP were identical with those used earlier (Hashimoto et al. 2001, Farkas et al. 2017).

\section{Light and electron microscopical morphology}

Testes of 3-month-old wild-type (WT) ( $n=11)$, heterozygous $(\mathrm{HZ})(n=10)$ and $\mathrm{KO}$ mice $(n=8)$ were fixed in Bouin fixative containing $75 \mathrm{~mL}$ picric acid in saturated aqueous solution, $25 \mathrm{~mL}$ formalin (40\% aqueous solution) and $5 \mathrm{~mL}$ glacial acetic acid, and then embedded in paraffin. Serial sections were made and HE staining was performed (HE, Sigma-Aldrich). Photomicrographs were taken using an Olympus DP72 camera on a Nikon Eclipse E800 microscope. Sperms from a separate group of WT and $\mathrm{KO}$ animals were also investigated with electron microscopy ( $n=5-5 \mathrm{WT}$ and KO). For electron microscopic evaluation, epididymis-derived sperms were fixed in $2 \%$ of formaldehyde and $2.5 \%$ of glutaraldehyde fixative overnight in $4^{\circ} \mathrm{C}$ after dissection. Samples were washed and dehydrated. One drop of the supernatant was dropped on a glass surface, and it was sputter coated with gold. Samples were examined and photographed in a JEOL 1200EX electron microscope.

\section{Evaluation of sperm quality}

Sperms were collected from the caudal part of the epididymis after cervical dislocation of 3-month-old adult male mice ( $n=18 \mathrm{WT}, n=9 \mathrm{HZ}$ and $n=16 \mathrm{KO}$ ). The dissected caudal epididymis was placed in phosphate buffered saline (PBS) supplemented with $10 \%$ BSA and torn apart into small pieces followed by 5 -min incubation on a warming plate at $37.5^{\circ} \mathrm{C}$. During incubation, the spermatozoa had time to swim out of the epididymal duct. Obtained sperms were placed in PBS. Following $5 \mathrm{~min}$ of incubation on a warming plate at $37.5^{\circ} \mathrm{C}$, sperm motility was measured with CASA System (Medealab, Erlangen, Germany). For every sample, a total of 6 fields were examined giving an evaluation of approximately 900 cells per sample. Each field was recorded for $8 \mathrm{~s}$ (total of $48 \mathrm{~s}$ per sample). Sperms were divided into 4 groups based on motility: group A (rapid progressive), B (medium progressive), C (nonprogressive) and D (immotile). Sperm morphology (categories: normal, proximal or distal plasma droplets, detached head, bent tail, microcephaly, macrocephaly) and acrosome 
integrity (presence or absence of acrosome) were evaluated with Spermac staining (Beernem, Belgium). Minimum 200 cells were examined for the morphological analysis. After the measurement of untreated sperms, $5 \mu \mathrm{L}$ of $100 \mathrm{nmol}$ PACAP138 synthesized as previously described (Jozsa et al. 2005), dissolved in $495 \mu \mathrm{L}$ PBS, was added to the samples that were incubated at $37^{\circ} \mathrm{C}$ for $5 \mathrm{~min}$ in order to investigate the effects of the exogenous peptide on motility (Brubel et al. 2012).

\section{Immunohistochemistry}

Immunohistochemistry was performed on WT $(n=5), \mathrm{HZ}(n=5)$ and $\mathrm{KO}(n=5)$ testis samples to visualize the localization of P-Sox9, Sox10 and collagen type IV (Col. IV). Testes were fixed in Saint-Marie's fixative and washed in $70 \%$ ethanol. After embedding serial sections were made, deparaffination was then followed by rinsing in PBS ( $\mathrm{pH}$ 7.4). Non-specific binding sites were blocked with PBS supplemented with $1 \%$ bovine serum albumin (Amresco LLC, Solon, OH, USA), following which the samples were incubated with polyclonal P-Sox9 (Sigma-Aldrich), Sox10 (Abcam) or Col. IV (Abcam) antibodies at a dilution of $1: 600$ at $4{ }^{\circ} \mathrm{C}$ overnight. For visualization of the primary antibodies, anti-rabbit Alexa fluor 555 secondary antibody (Life Technologies) was used at a dilution of 1:1000. Samples were mounted in Vectashield mounting medium (Vector Laboratories, Peterborough, England) containing DAPI for nuclear DNA staining. For negative controls, anti-rabbit Alexa fluor 555 was used without the primary antibodies, which did not result in any positive signal (not shown). Photomicrographs of the tissues were taken using an Olympus DP72 camera on a Nikon Eclipse E800 microscope (Nikon). Images were acquired using cell Sens Entry 1.5 software (Olympus) with constant camera settings to allow comparison of fluorescent signal intensities. Images of Alexa555 and DAPI were overlaid using Adobe Photoshop, version 10.0 software.
The contrast of images was increased equally without changing constant settings.

\section{RT-PCR analysis}

Testes of WT, HZ and $\mathrm{KO}$ mice $(n=5)$ were mechanically ground and were dissolved in TRIzol (Applied Biosystems), after 30-min incubation at $4{ }^{\circ} \mathrm{C}$ total RNA was isolated. RNA was harvested in RNase-free water and stored at $-70^{\circ} \mathrm{C}$. Reverse transcription was performed by using HighCapacity RT kit (Applied Biosystems). For the sequences of primer pairs and details of polymerase chain reactions, see Table 1. Amplifications were performed in a thermal cycler (Labnet MultiGene 96-well Gradient Thermal Cycler; Labnet International, Edison, NJ, USA) as follows: at $95^{\circ} \mathrm{C}$ for $2 \mathrm{~min}$, followed by 35 cycles (denaturation at $94^{\circ} \mathrm{C}$ for $30 \mathrm{~s}$; annealing for $45 \mathrm{~s}$ at optimized temperatures as given in Table 1; extension, $72^{\circ} \mathrm{C}, 90 \mathrm{~s}$ ) and then $72^{\circ} \mathrm{C}, 7 \mathrm{~min}$. Glyceraldehyde 3-phosphate dehydrogenase (Gapdh) was used as internal control. PCR products were analyzed using a $1.2 \%$ agarose gel containing ethidium bromide. Optical densities of PCR product signals were determined by using Image $1.40 \mathrm{~g}$ freeware.

\section{Western blot analysis}

Testes of WT $(n=5), \mathrm{HZ}(n=5)$ and KO mice $(n=5)$ were washed in physiological saline and stored at $-70^{\circ} \mathrm{C}$. Samples were mechanically disintegrated with a tissue grinder in liquid nitrogen. Then, they were collected in $100 \mu \mathrm{L}$ of homogenization radioimmunoprecipitation assay (RIPA) buffer $(150 \mathrm{mM}$ sodium chloride; $1.0 \%$ NP40, 0.5\% sodium deoxycholate; $50 \mathrm{mM}$ Tris, $\mathrm{pH} 8.0$ ) containing protease inhibitors (aprotinin $(10 \mu \mathrm{g} / \mathrm{mL}), 5 \mathrm{mM}$ benzamidine, leupeptin $(10 \mu \mathrm{g} / \mathrm{mL})$, trypsin inhibitor $(10 \mu \mathrm{g} / \mathrm{mL}), 1 \mathrm{mM}$ PMSF, $5 \mathrm{mM}$ EDTA, $1 \mathrm{mM}$ EGTA, $8 \mathrm{mM}$ Na-Fluoride, $1 \mathrm{mM}$ Na-orthovanadate). The suspensions

Table 1 Nucleotide sequences, amplification sites, GenBank accession numbers, amplimer sizes and PCR conditions for each primer pair are shown.

\begin{tabular}{|c|c|c|c|c|c|}
\hline Gene & Primer & Nucleotide sequence $\left(5^{\prime} \rightarrow 3^{\prime}\right)$ & GenBank ID & $\begin{array}{c}\text { Annealing } \\
\text { temperature }\end{array}$ & $\begin{array}{l}\text { Amplimer size } \\
\text { (bp) }\end{array}$ \\
\hline \multirow[t]{2}{*}{ PKA (Prkaca) } & Sense & GCA AAG GCT ACA ACA AGG C (847-865) & NM_001277898.1 & $54^{\circ} \mathrm{C}$ & 280 \\
\hline & Antisense & ATG GCA ATC CAG TCA GTC G (1108-1126) & & & \\
\hline \multirow[t]{2}{*}{ ERK (Mapk1) } & Sense & CCG TGA CCT CAA GCC TTC C (1732-1750) & NM_011949.3 & $58^{\circ} \mathrm{C}$ & 163 \\
\hline & Antisense & ATG CAG CCC ACA GAC CAA A (1877-1894) & & & \\
\hline \multirow[t]{2}{*}{ p38 (Mapk14) } & Sense & GAG GTG CCC GAA CGA TAC (453-470) & NM_011951.3 & $53^{\circ} \mathrm{C}$ & 144 \\
\hline & Antisense & TTT GGC GTG AAT GAT GGA (579-596) & & & \\
\hline \multirow[t]{2}{*}{ Sox9 } & Sense & GTA CCC GCA TCT GCA CAA CG (378-397) & NM_011448 & $62^{\circ} \mathrm{C}$ & 521 \\
\hline & Antisense & GTG GCA AGT ATT GGT CAA ACT CAT T (874-898) & & & \\
\hline \multirow[t]{2}{*}{ Sox 10} & Sense & ACG ACT GGA CGC TGG TGC (535-552) & NM_011437.1 & $58^{\circ} \mathrm{C}$ & 283 \\
\hline & Antisense & CGC CGA GGT TGG TAC TTG TAG (797-817) & & & \\
\hline \multirow[t]{2}{*}{ PP2A (Ppp2ca) } & Sense & CTC TGC GAG AAG GCT AAA (288-305) & NM_017039.2 & $54^{\circ} \mathrm{C}$ & 436 \\
\hline & Antisense & TGA TTC CCT CGG AGT ATG (706-723) & & & \\
\hline \multirow[t]{2}{*}{ Collagen IV (Col4a1) } & Sense & TCG GCT ATT CCT TCG TGA TG (4963-4982) & NM_009931.2 & $52^{\circ} \mathrm{C}$ & 209 \\
\hline & Antisense & GGA TGG CGT GGG CTT CTT (5154-5171) & & & \\
\hline \multirow[t]{2}{*}{ Collagen IX (Co/9a3) } & Sense & CAG GTT CCG ATG GTC TTC C (1357-1375) & NM_009936.2 & $55^{\circ} \mathrm{C}$ & 492 \\
\hline & Antisense & CTG TTG СTC ССT TGT CCC (1831-1848) & & & \\
\hline \multirow[t]{2}{*}{ Testatin (Cys9) } & Sense & CTG GAG GGA GAA GGT AAA (274-291) & NM_009979.1 & $51^{\circ} \mathrm{C}$ & 142 \\
\hline & Antisense & CAG GCA GGT GAA GGT ATT (398-415) & & & \\
\hline \multirow[t]{2}{*}{ GAPDH } & Sense & TGG CAA AGT GGA GAT TGT TG (238-258) & NM_008084.2 & $59^{\circ} \mathrm{C}$ & 486 \\
\hline & Antisense & GTC TTC TGG GTG GCA GTG AT (775-793) & & & \\
\hline
\end{tabular}


Table 2 Antibodies used in the experiments.

\begin{tabular}{llll}
\hline Antibody & Host animal & Dilution & Distributor \\
\hline Anti-Col. IX. & Rabbit, PC & $1: 500$ & Abcam \\
Anti-Col. IV. & Rabbit, PC & $1: 800$ & Abcam \\
Anti-Testatin. & Rabbit, PC & $1: 300$ & Santa Cruz Biotechnology \\
Anti-PKA C & Rabbit, PC & $1: 800$ & Cell Signaling \\
Anti-ERK1/2 & Rabbit, PC & $1: 1000$ & Sigma-Aldrich \\
Anti-P-ERK/12 & Mouse, MC & $1: 800$ & Sigma-Aldrich \\
Anti-p38 & Rabbit, PC & $1: 1000$ & Cell Signaling \\
Anti-P-p38 & Rabbit, PC & $1: 800$ & Cell Signaling \\
Anti-Sox9 & Rabbit, PC & $1: 800$ & Abcam \\
Anti-P-Sox9 & Rabbit, PC & $1: 800$ & Sigma-Aldrich \\
Anti-Sox10 & Rabbit, PC & $1: 500$ & Abcam \\
Anti-PP2A C & Rabbit, PC & $1: 600$ & Cell Signaling \\
Anti-Actin & Mouse, MC & $1: 10,000$ & Sigma-Aldrich \\
\hline
\end{tabular}

$\mathrm{PC}$, polyclonal; $\mathrm{MC}$, monoclonal

were sonicated by pulsing burst for $30 \mathrm{~s}$ at $40 \mathrm{~A}$ (Cole-Parmer, Vernon Hills, IL, USA). Total cell lysates for Western blot analyses were prepared. Twenty micrograms of protein were separated in 7.5\% SDS-polyacrylamide gels for the detection of PKA, ERK 1/2, P-ERK 1/2, p38, P-p38, Sox9, P-Sox9, Sox10, PP2A, collagen type IV (Col. IV), collagen type IX (Col. IX), testatin and actin. Proteins were transferred by electrophoresis to nitrocellulose membranes and exposed to the primary antibodies overnight at $4{ }^{\circ} \mathrm{C}$ in the dilution as given in Table 2. After washing for $30 \mathrm{~min}$ with PBST, membranes were incubated with the peroxidase-conjugated secondary antibody anti-rabbit IgG in a 1:1500 (Bio-Rad Laboratories) or anti-mouse IgG in 1:1500 (Bio-Rad Laboratories) dilution. Signals were detected with enhanced chemiluminescence (Advansta, Menlo Park, CA, USA) according to the instructions provided by the manufacturer. Actin was used as an internal control. Signals were developed with gel documentary system (Fluorchem E, ProteinSimple, San JoseCA, USA). Optical densities of signals were measured by using ImageJ $1.40 \mathrm{~g}$ freeware.

\section{In vitro protein phosphatase $2 A$ (PP2A) activity assay}

PP2A activity was assayed with ${ }^{32} \mathrm{P}$-labeled myosin light-chain $(5 \mu \mathrm{M})$ in testes of WT $(n=5), \mathrm{HZ}(n=5)$ and $\mathrm{KO}$ mice $(n=5)$ as described previously (Erdodi et al. 1995). Briefly, pellets were suspended in $10 \mathrm{mM}$ Tris/ $\mathrm{HCl}(\mathrm{pH} 7.4), 0.1 \mathrm{mM}$ EGTA, $0.25 \mathrm{mM}$ dithiothreitol, $0.1 \mathrm{mM}$ PMSF, $0.1 \mathrm{mM}$ DFP, $0.1 \mathrm{mg} / \mathrm{mL}$ leupeptin and $1 \mathrm{mM}$ benzamidine (buffer $\mathrm{A}$ ) and further diluted in buffer A supplemented with $1 \mathrm{mg} / \mathrm{mL}$ BSA. One unit of the protein phosphatase activity releases $1 \mu \mathrm{mol}$ of $\mathrm{P}_{\mathrm{i}}$ from the phosphosubstrate per min at $30^{\circ} \mathrm{C}$.

\section{Statistical analysis}

All data presented are representative of at least three independent experiments. Statistical analysis was performed by ANOVA and unpaired Student's t-test. The threshold for statistically significant differences as compared to controls was set at $* P<0.05$.

\section{Results}

\section{Morphology of seminiferous tubules, sperm motility and morphology}

The general characteristics of seminiferous tubules were visualized with $\mathrm{HE}$ staining and morphological comparisons were made in WT and PACAP KO mice. No alterations were seen in tubular structures, and the general location of the differentiating cells was similar in all experimental groups (Fig. 1A). Regarding sperm morphology, there was no difference in the electron microscopical structure (Fig. 1B). No difference was seen in the structure of $\mathrm{HZ}$ mice either (not shown).

Results of groups A and B sperms (rapid and medium progressive) were combined as well as those from groups $C$ and $D$ (non-progressive and immotile). The ratio of the sperms with good motility $(A+B)$ and weak or no motility $(C+D)$ was $65.6 / 34.4 \%$ in the wild-type animals, 60.6/39.8 in HZ mice and 68.7/31.3 in $\mathrm{KO}$ sperms (Fig. 1D). There was no significant difference

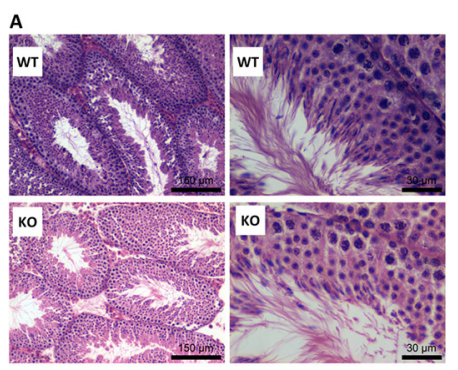

C
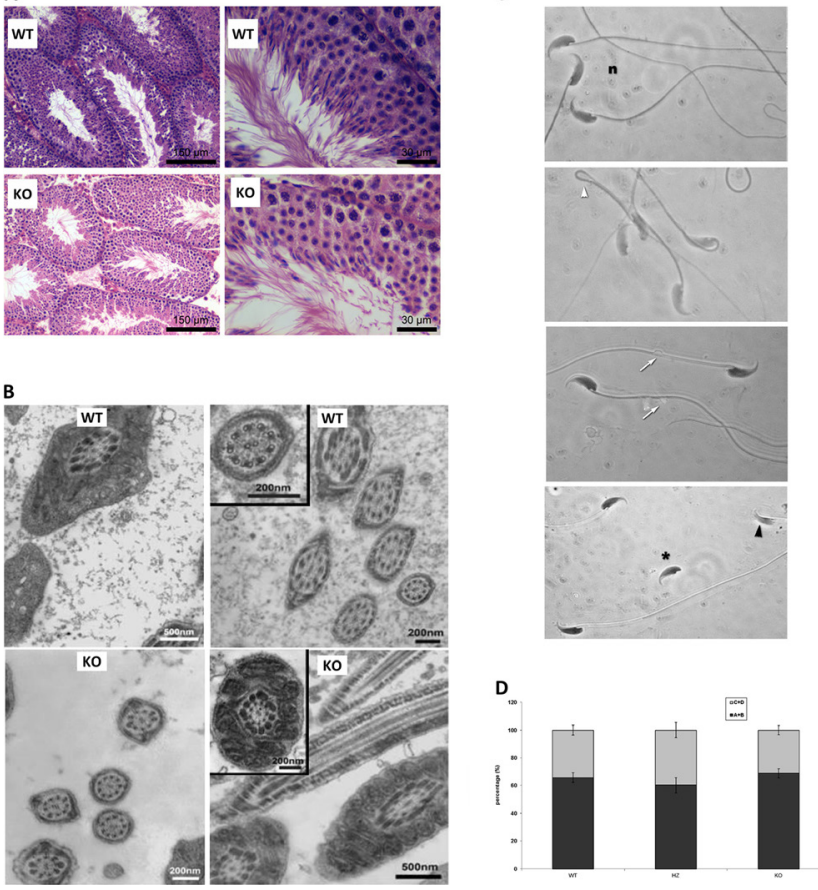

Figure 1 (A) Representative microphotograph of WT and KO seminiferous tubules stained with hematoxylin and eosin. Overview of several tubules and higher magnification view of the wall of one seminiferous tubule. (B) Electron microscopical analysis of WT and KO sperms. (C) Representative images of spermatozoa showing normal and most common abnormal morphologies. White arrow: plasma droplet; white arrowhead: hairpin tail; black arrowhead: acrosome deficiency; asterisk: detached head; n: normal morphology. (D) Motility of sperms: A (rapid progressive), B (medium progressive), C (non-progressive), D (immotile). Data are represented as A+B (progressive) and $C+D$ (non-progressive and immotile) together. Data are given as mean \pm S.E.M. 
between any of the parameters. Addition of PACAP did not significantly change motility in any of the groups (data not shown). These results show that neither exogenous nor endogenous PACAP changed sperm motility in mice. Examining the morphology, we could not confirm statistical differences, in spite of the $10 \%$ less normal sperms in $\mathrm{KO}$ mice (percentage of normal sperms was $69.6 \pm 3.1 \%, 68.8 \pm 8.1$ and $58.8 \pm 6.7$ in $\mathrm{WT}, \mathrm{HZ}$ and $\mathrm{KO}$ mice, respectively). The standard deviation was high, but there were a few $\mathrm{KO}$ mice with no normal sperms at all, with the detached head being the most apparent abnormal sign (Fig. 1C).

\section{PKA and MAPK pathways had modified activation in gene-deficient animals}

Expression of canonical targets of PACAP receptor activation such as PKA and MAPKs were examined by RT-PCR and Western blot. Although the mRNA expression of PKA did not show any alterations in $\mathrm{HZ}$ or $\mathrm{KO}$ mice, its protein expression was significantly decreased in $\mathrm{KO}$ animals, and it was expressed at higher levels in testis samples of $\mathrm{HZ}$ mice than in WT controls (Fig. 2A and B). mRNA and protein expression of ERK1/2 were similar in the three experimental groups. The phosphorylated form of ERK1/2 represents a more active form of this MAPK, which may have an influence on cell proliferation.

\section{A. RT-PCR}

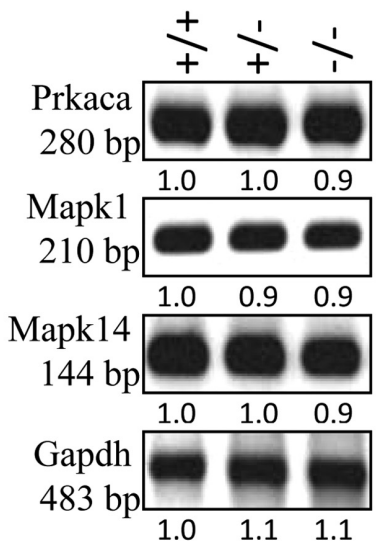

\section{B. Western blot}

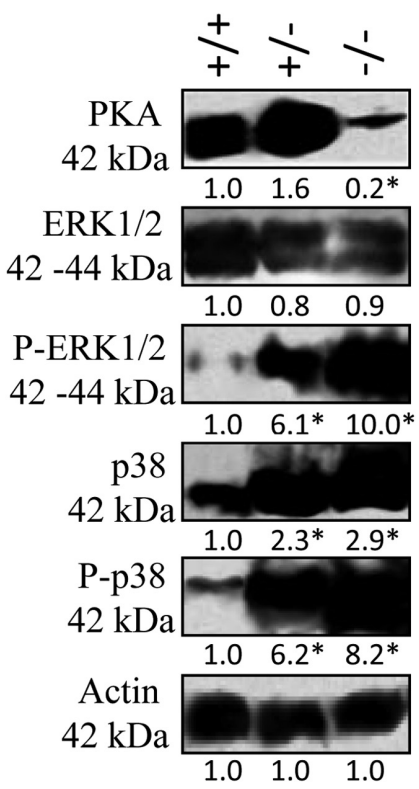

Figure 2 Optical density of signals was measured and results were normalized to the optical density of controls. For panels (A) and (B), numbers below the signals represent integrated densities of signals determined by ImageJ software. Asterisks indicate significant $\left({ }^{*} P<0.05\right)$ alteration of expression as compared to the respective control. Representative data of 3 independent experiments. WT (+/+), $\mathrm{HZ}(+/-)$, PACAP KO (-/-). For RT-PCR reactions GAPDH and for Western blot actin were used as controls.
$\mathrm{HZ}$ and PACAP KO mice showed a significantly increased P-ERK1/2 level (Fig. 2A and B). p38 is another possible MAPK that can be involved in PACAP-induced signaling pathways. Its mRNA expression did not show alterations, but significantly higher protein expression and P-p38 were detected in the $\mathrm{HZ}$ and $\mathrm{KO}$ mice than in WT controls (Fig. 2A and B).

\section{Possible downstream targets of PKA in PACAP KO mice}

The activation of Sox9, a major transcription factor of testis development and spermatogenesis, can be regulated by PKA as a canonical downstream target of PAC1 receptor activation. The mRNA expression of Sox9 was not altered in $\mathrm{HZ}$ or $\mathrm{KO}$ animals (Fig. 3A). Although Sox9 protein expression was unchanged in $\mathrm{HZ}$ mice, it was significantly decreased in PACAP KO mice. The level of the more active phosphorylated form
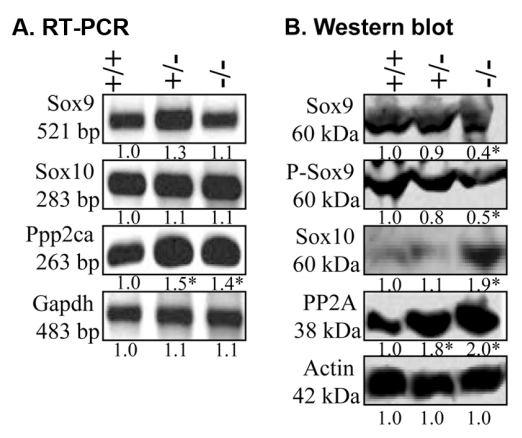

C. PP2A activity assay

D. P-Sox9 immunohistochemistry
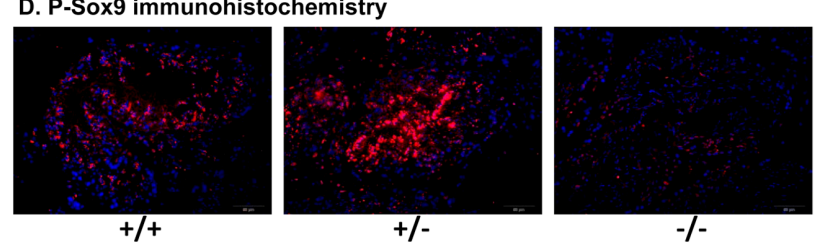

E. Sox10 immunohistochemistry

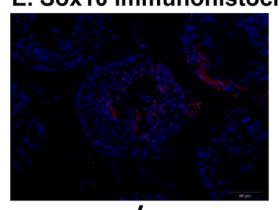

$+/+$

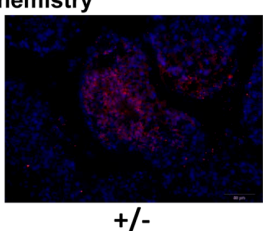

$+/-$

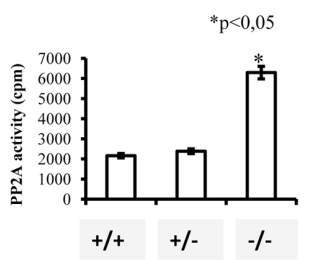

Figure 3 Optical density of signals was measured and results were normalized to the optical density of controls. For panels (A) and (B), numbers below the signals represent integrated densities of signals determined by ImageJ software. Asterisks indicate significant $\left({ }^{*} P<0.05\right)$ alteration of expression as compared to the respective control. Representative data of 3 independent experiments. (C) PP2A enzyme activity determined in a cell-free in vitro assay from lysates of WT, HZ and PACAP KO samples. Significant difference between PP2A enzyme activity in HZ and PACAP KO samples vs control lysates is marked by asterisks $(* P<0.05)$. (D and $E)$

Immunohistochemistry of P-Sox9 and Sox10 in seminiferous tubules. Magnification was made with $20 \times$ objective. Scale bar: $50 \mu \mathrm{m}$. WT $(+/+), \mathrm{HZ}(+/-)$, PACAP KO (-/-). For RT-PCR Gapdh and for Western blot reactions actin were used as controls. 
of Sox9 also showed a reduction similar to the nonphosphorylated version in homogenous gene-deficient mice (Fig. 3B), but again the protein expression was not significantly altered in $\mathrm{HZ}$ mice (Fig. 3B). Next, we investigated the localization of P-Sox9 in seminiferous tubules and its immunopositivity was detected in the outer region of WT animals. In HZ animals expression of P-Sox9 was strongly localized close to the lumen of seminiferous tubules with a very weak peripheral presence (Fig. 3D). Immunohistochemical results indicated lower immunopositivity of P-Sox9 detected in all parts of the seminiferous tubules of PACAP KO mice (Fig. 3D). Sox10 is another important regulatory factor of testis development/spermatogenesis, and it can substitute the function of Sox9. mRNA expression of this transcription factor was constant in the investigated samples (Fig. 3A). Unexpectedly, Sox10 expression was significantly elevated in PACAP KO mice, while it was not altered in $\mathrm{HZ}$ mice (Fig. 3B). Immunopositivity of Sox 10 in WT and HZ mice was very weak and randomly appeared in the cells of seminiferous tubules. On the contrary, strong Sox10 signals were detected in the middle portion of tubules in $\mathrm{KO}$ animals (Fig. 3E).

\section{Phosphatase function}

The phosphorylation and, consequently, activation of Sox9 are regulated by the Ser/Thr phosphatase called PP2A, which can reversibly dephosphorylate the targets of PKA. As the decreased phosphorylated Sox9 expression can be the result of an increased PP2A activity, we monitored the phosphatase function in the testis. Interestingly, the mRNA and protein levels of PP2A showed a significant elevation in $\mathrm{HZ}$ and PACAP $\mathrm{KO}$ mice (Fig. $3 \mathrm{~A}$ and $\mathrm{B}$ ). The increased expression of the phosphatase is not always followed by more intense activity; therefore, we measured the PP2A activity in the testis samples. In PACAP KO mice, the phosphatase activity was dramatically increased. No differences were detected between the WT and HZ groups (Fig. 3C).

\section{Target genes of Sox transcription factors in testis development}

Possible targets of Sox transcription factors can be collagen type IV (Col. IV), collagen type IX (Col. IX) or testatin, major components of the basal lamina of the tubules. The mRNA expression of testatin was not altered, while that of Col4a showed a significant decrease in $\mathrm{HZ}$ and $\mathrm{KO}$ mice (Fig. 4A). However, the protein expression of this basement membrane component showed a significant decrease in $\mathrm{HZ}$ and PACAP KO mice (Fig. 4B). The mRNA expression of Col. IX protein was moderately reduced in gene-deficient mice, while its protein expression was elevated in both $\mathrm{HZ}$ and PACAP KO rodents (Fig. 4A and B). The other testisspecific basement membrane component is testatin, the protein expression of which was dramatically increased in PACAP KO mice (Fig. 4A and B). As these observations may reflect a possible alteration in the basement membrane integrity, immunohistochemistry was performed to detect structural differences of basal membrane Col. IV. In WT mice, the integrity of the basement membrane was strongly detected around the seminiferous tubules. $\mathrm{HZ}$ animals showed a weaker Col. IV immunoreaction, which further decreased in PACAP $\mathrm{KO}$ animals (Fig. 4C).

\section{Discussion}

In the present study, we described that several factors playing an important role in spermatogenesis are significantly influenced by partial or complete lack of PACAP. In spite of the unaltered or only slightly altered morphology and motility of spermatozoa of PACAP-deficient animals, the disturbed molecular

\section{A. RT-PCR}

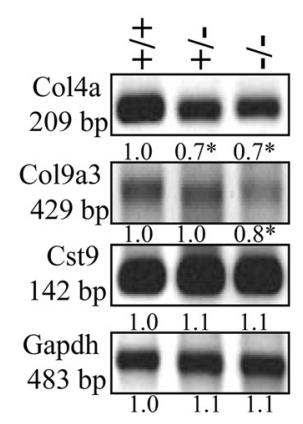

\section{B. Western blot}

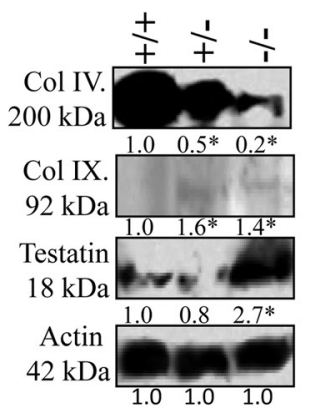

\section{Coll type IV. immunohistochemistry}
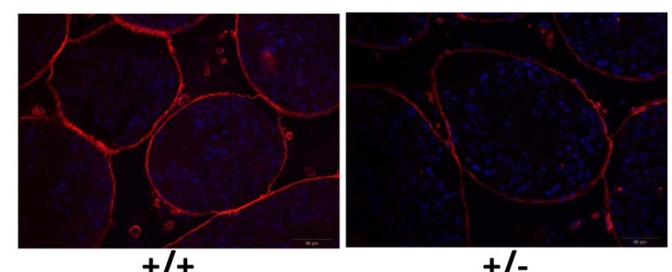

$+/-$

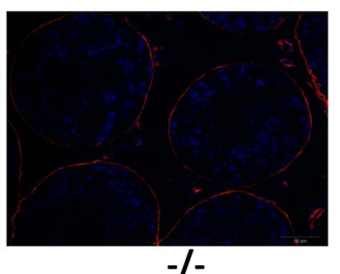

$-/-$

Figure 4 Downstream targets of Sox transcription factors altered in PACAP knockout mice. mRNA (A) and protein (B) expression of Col. IV, Col. IX and testatin. For RT-PCR Gapdh and for Western blot reactions actin were used as controls. Optical density of signals was measured and results were normalized to the optical density of controls. For panels (A) and (B) numbers below the signals represent integrated densities of signals determined by Image software. Asterisks indicate significant $\left({ }^{*} P<0.05\right)$ alteration of expression as compared to the respective control. Representative data of 3 independent experiments. (C) Immunohistochemistry of Col. IV in seminiferous tubules. Magnification was made with $20 \times$ objective. Scale bar: $50 \mu \mathrm{m}$. WT (+/+), HZ (+/-), PACAP KO (-/-). 


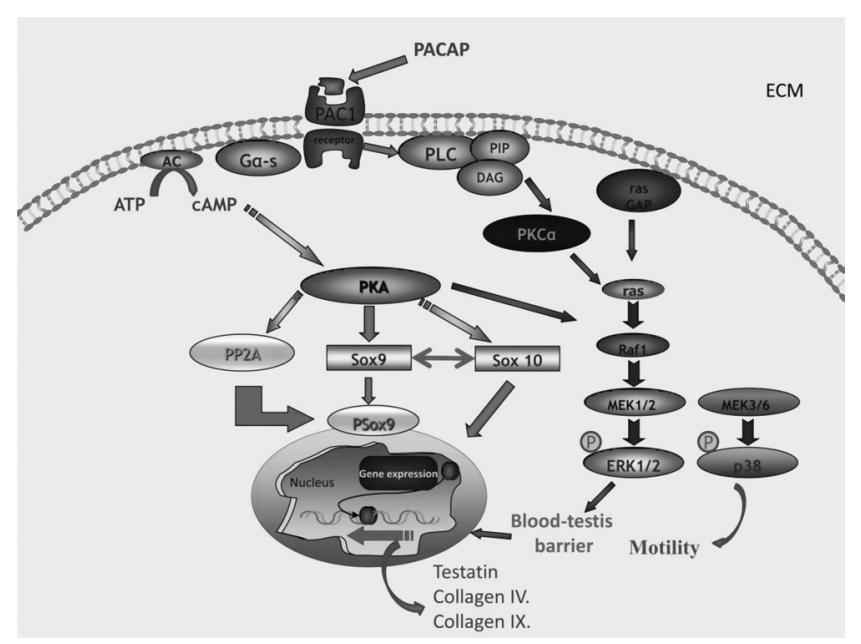

Figure 5 Schematic drawing of the possible signaling pathways regulated by PACAP in spermatogenesis. PAC1 receptor activation leads to the increase of intracellular CAMP, which activates PKA. Downstream targets of PKA are partly regulated by Ser/Thr reversible phosphorylation. PP2A can regulate the dephosphorylation of the transcription factor Sox9, which can modify the expression or activation of Sox10. Additionally, PKA can influence ERK1/2 phosphorylation. Parallel with these events, p38 activation can also take place. Main targets of Sox 9 transcription factor can be Collagen type IV, Collagen type IX or Testatin. These reversible phosphorylation events may regulate proliferation, motility or formation of bloodtestis barrier.

mechanisms in spermatogenesis may account for some of the known perturbations in the fertility of PACAP $\mathrm{KO}$ mice. The possible effects of PACAP on signaling mechanisms are summarized in Fig. 5 and discussed in the following sections.

Several studies have shown the presence of PACAP, its mRNA and receptors in the testis and epididymis of different vertebrate species and in the human testis (Kononen et al. 1994, Agnese et al. 2010, 2016, Rosati et al. 2014) after the pioneer study of Arimura et al. (1991), which showed that testis contained the highest levels of PACAP among the peripheral organs. Lv et al. (2011) described the gradual increase of PACAP mRNA in the rat testis from day 20 after birth, reaching the maximum level on day 60, mainly in spermatocytes and round spermatids. Similarly, the epididymis showed a gradual increase in PACAP during puberty (Lv et al. 2011). Other studies found stage-specific expression of PACAP: while high levels of expression could be found in most developing germ cells, PACAP expression is lacking in mature spermatids according to some reports (Yanaihara et al. 1998). Tanii and coworkers have described weak immunostaining in mature sperm heads (Tanii et al. 2011). The expression of PACAP has been shown to be influenced by several factors, but its regulation in the testis is not yet entirely understood. Raising the temperature to body temperature by inducing experimental cryptorchidism can lead to a dramatic decrease of PACAP mRNA both in the testis and epididymis (Lv et al. 2011). It is possible that this and other, yet unknown, influencing factors are responsible for the stage-specific expression of PACAP during the spermatogenic cycle and are responsible for the discrepancies found between descriptions (Rosati et al. 2014). A testis-specific splice variant of the PAC1 receptor has also been reported (Daniel et al. 2001). Interestingly, unlike in other tissues, PACAP38 and 27 were found to have the same levels in human testis as shown by radioimmunoassay (Tamas et al. 2016). No differences were found in the level of PACAP peptides between normal tissues and seminomas (Tamas et al. 2016), but a different distribution pattern was observed in different tumor biopsies by Nakamura et al. (2014). In addition to the local production of PACAP, circulating PACAP can additionally contribute to testicular functions of the peptide, as it has been shown that PACAP can cross the blood-testis barrier (Banks et al. 1993, Mizushima et al. 2001). Testis functions in PACAP gene-deficient animals had only been studied by Lacombe et al. (2006). This study revealed interesting results in the testis: unlike in any other organ/system investigated so far, testicular aging was delayed in PACAP-deficient mice with a decreased level of apoptosis and decreased oxidative stress markers (Lacombe et al. 2006). The authors argued that the stimulatory effect of PACAP on steroidogenesis may result in a higher level of its byproduct reactive oxygen species production, leading to testicular aging, but also supporting the role of PACAP played in normal testicular function at younger ages. Our present results of normal testicular histology in PACAP KO mice at a young age are in accordance with the findings of Lacombe and coworkers (Lacombe et al. 2006).

The high level of PACAP and its stage-specific expression pattern indicate that the peptide plays important roles in spermatogenesis. It has been described that PACAP influences hormonal secretion via regulating Leydig and Sertoli cell growth and functions, as well as acrosome reaction during fertilization (Tanii et al. 2011). Influencing motility is also among the possible functions of PACAP, as our previous report showed that PACAP could increase the motility of abnormally slow-moving human sperms (Brubel et al. 2012). The results of Gozes and coworkers showing that addition of a PACAP antagonist peptide led to a decrease in motility provided a proof for the possible endogenous stimulatory effect of PACAP (Gozes et al. 1998). However, our present finding that mice deficient in PACAP show normal motility implies that even if present, the endogenous effects of PACAP on motility can be compensated by other factors. Furthermore, exogenous PACAP did not alter the sperm motility in the present study. This observation is in accordance with our earlier description in human sperms (Brubel et al. 2012), where we found that the motility of only slow-moving sperms could be increased by PACAP with normal moving sperms not influenced. Our previous study also described 
that sperm heads from PACAP-deficient mice were significantly smaller than those from wild types (Brubel et al. 2012). This observation further implies that PACAP is necessary for normal spermatogenesis. Our present findings also support this observation: the percentage of normal sperms was $10 \%$ lower in PACAP KO mice than in the other two groups, even if due to the high deviation, this was not statistically significant. Among the abnormal sperms, more sperms had detached heads in the PACAP KO group. In spite of some differences, our present results show that reduced fertility in PACAP KO mice is most probably not due to altered morphology or motility, since differences were slight. However, we revealed marked differences in the molecular factors and targets of PACAP-induced signaling pathways.

PACAP, binding to its receptors, induces intracellular CAMP accumulation, and subsequently activates PKA, also known as the canonical downstream signaling pathway. As expected, the expression of PKA was reduced in the samples of KO mice. PKA has a crucial role in germ cell development and differentiation; therefore, its lower activity can result in lower fertility, decreased sperm number or reduced capacitation capability (Burton \& McKnight 2007). The inactivation of PKA by the lack of PACAP may influence spermatogenesis or spermiogenesis. However, PKA pathways have several cross-talks; thus, the lack of PKA has compensation possibilities.

It is also known that PACAP receptor activation can communicate with other kinases such as ERK1/2 and p38 (Racz et al. 2007), which may influence cell survival, proliferation and differentiation. Therefore, we monitored the expression of these MAPKs. Protein expression of p38 and of the more active phosphorylated form of ERK1/2 and p38 increased in PACAP-deficient testes. ERK1/2 functions have been described in the testis: it can regulate cell renewal in goat spermatogonia (Niu et al. 2015) and affects Sertoli cell junction, blood-testis barrier and division of spermatogonia (Siu et al. 2005, Wong \& Cheng 2005). Our data suggest that the elevated expression of P-ERK1/2 can be a compensatory effect of the lower PKA activation, ensuring the spermatogenesis with the activation of other downstream signalization in a PKAindependent manner. p38 also plays role in the Sertoli cell adhesion stability and has some regulatory effect on elongated spermatids (Wong \& Cheng 2005) triggering normal motility. Thus, the effect of p38 in PACAP KO animals can be dual in testis, partly maintaining a functional blood-testis barrier and supporting the normal cell motility of spermatids. On the one hand, the increased phosphorylation of p38 alters the apoptotic processes in spermatogonia resulting in an abnormal differentiation with altered sperm morphology. On the other hand, PKA can phosphorylate several transcription factors, which play unique roles in testis development and spermatogenesis.
The members of SoxE transcription factors such as Sox8, Sox9 and Sox10 have fundamental functions in several developmental processes, including testis development (Barrionuevo \& Scherer 2010, Georg et al. 2012). Sox9 is required for maintenance of the integrity of Sertoli cells in adult testis (Barrionuevo et al. 2016). Loss of function of Sox10 had no effect on testis development (Barrionuevo \& Scherer 2010) but a crossregulation has been proven between Sox 9 and Sox10 in other cells, such as melanocytes (Shakhova et al. 2015). The reduced expression and phosphorylation of Sox9 in PACAP KO mice suggest a direct signalization with PKA as it has been shown in chondrogenic cells (Zákány et al. 2005). Moreover, it has been demonstrated that PAC1 receptor activation increases the level of P-Sox9 in chondrogenic cell cultures (Juhász et al. 2014a), which further supports the possible PKA-Sox9 signalization axis. The elevated Sox10 expression proves a possible substitution of Sox9 function, therefore, the increased level of Sox10 may compensate for the lower activity of Sox9, resulting in a normal blood-testis barrier. On the other hand, expression profiles in $\mathrm{HZ}$ animals were disturbed, also suggesting an interrupted Sox9Sox10 crosstalk. A recent study has demonstrated that some signs of neurobehavioural development are more disturbed in mice partially lacking PACAP than in mice with a complete lack of the peptide (Farkas et al. 2017), implying disturbed compensatory processes in some signaling pathways.

Transcription factors phosphorylated by PKA can be dephosphorylated by a Ser/Thr phosphatase, PP2A (Zákány et al. 2005, Juhász et al. 2014b). PP2A was demonstrated influencing spermatid maturation (Hatano et al. 1993) and differentiation of Sertoli cells (Levallet et al. 2013). Furthermore, the inhibitory effect of PACAP on PP2A has been detected in chromaffin cells (Bobrovskaya et al. 2007), but no data are available for the testis. According to our results, the absence of PACAP results in an increased PP2A activity, which can partly be responsible for the lower phosphorylation of Sox9 (Zákány et al. 2005). Therefore, the transcriptional inactivation can be a consequence of lower PKA activity and a parallely increased PP2A function. Sox9 can be translocated into the nuclei of Sertoli cells and can regulate certain gene expression. Col. IV is one of the major elements of the basement membrane in the seminiferous tubules and regulates the formation of the blood-testis barrier (Harvey et al. 2006). Col. IX also has some functions in the maintenance of the basement membrane, consequently the blood-testis barrier (McClive \& Sinclair 2003). Furthermore, testatin has also been proven to have a role in the regulation of testis development (Georg et al. 2012). The genes of these proteins may be regulated by Sox 9 as a termination of the PAC1-PKA-Sox9 axis. As we demonstrated, the protein level of Col. IV in the basement membrane of the seminiferous tubules was decreased; therefore, the 
basement membrane was not well discernible in PACAP $\mathrm{KO}$ animals. On the other hand, the expression of testatin and Col. IX was elevated, suggesting a possible upregulation by other members of the SoxE family such as Sox10. On the contrary, the mRNA expression of Col. IX and testatin was decreased indicating an altered transcriptional activation as it has been demonstrated in chondrogenic differentiation (Juhász et al. 2014a). Our findings also support the idea that SoxE family members, especially Sox9, are important transcription factors in blood-testis barrier dynamics, which can be precisely regulated by PACAP. Indeed, we detected elevated expression of Sox 10 in testes of PACAP KO mice.

In summary, our findings suggest a role of PACAP in Sox9 expression and phosphorylation in mouse testis. In addition to the direct effects of Sox9 on testis determination and male germ cell production, PACAP seems to play a role in the maintenance of proper molecular composition of the basement membrane of seminiferous tubules. These results could be additional factors responsible for the reduced fertility in PACAPknockout mice as well as further supporting the role of endogenous PACAP in reproductive functions.

\section{Declaration of interests}

The authors declare that there is no conflict of interest that could be perceived as prejudicing the impartiality of the research reported.

\section{Funding}

NKFI K115874, PD109644, K119759, PTE AOK Research Grant, MTA-TKI14016, GINOP-2.3.2-15-2016-00050 'PEPSYS', New National Excellence Program of the Ministry of Human Capacities (UNKP-16-4-IV.), KTIA_13_NAP-A-III/5, EFOP-3.6.1.-16-2016-00004 Comprehensive Development for Implementing Smart Specialization Strategies at the University of Pecs, Centre for Neuroscience of the University of Pecs, University of Debrecen (RH/751/2015). The project is co-financed by the European Union and the European Social Fund. Bolyai Janos Research Scholarship (J T, A T). Szodoray Lajos and Magyary Zoltán Funds by Hungarian Academy of Science and the European Union and the State of Hungary, co-financed by the European Social Fund in the framework of TÁMOP 4.2.4 (J T). A/2-11-1-2012-0001 National Excellence Program'. The present scientific contribution is dedicated to the 650th anniversary of the foundation of the University of Pecs, Hungary.

\section{References}

Agnese M, Valiante S, Angelini F, Laforgia V, Andreuccetti P \& Prisco M 2010 Pituitary adenylate cyclase activating polypeptide and its reeptor PAC1 in the testis of Triturus carnifex and Podarcis sicula. General and Comparative Endocrinology 168 256-261. (https://doi.org/10.1016/j. ygcen.2010.03.016)
Agnese M, Valiante S, Rosati L, Andreuccetti P \& Prisco M 2016 Pituitary adenylate cyclase-activating peptide (PACAP) and PAC1 receptor in the testis of cartilaginous fish Torpedo marmorata: a molecular and phylogenetic study. Comparative Biochemistry and Physiology B Biochemistry and Molecular Biology 191 26-35. (https://doi. org/10.1016/j.cbpb.2015.09.002)

Apa R, Lanzone A, Miceli F, Vaccari S, Macchione E, Stefanini M \& Canipari R 2002 Pituitary adenylate cyclase-activating polypeptide modulates plasminogen activator expression in rat granulosa cell. Biology of Reproduction 66 830-835. (https://doi.org/10.1095/ biolreprod66.3.830)

Apostolakis EM, Riherd DN \& O`Malley BW 2005 PAC1 receptors mediate pituitary adenylate cyclase-activating polypeptide- and progesteronefacilitated receptivity in female rats. Molecular Endocrinology $\mathbf{1 9}$ 2798-2811. (https://doi.org/10.1210/me.2004-0387)

Arimura A, Somogyvari-Vigh A, Miyata A, Mizuno K, Coy DH \& Kitada C 1991 Tissue distribution of PACAP as determined by RIA: highly abundant in the rat brain and testes. Endocrinology 129 2787-2789. (https://doi. org/10.1210/endo-129-5-2787)

Banks WA, Kastin AJ, Komaki G \& Arimura A 1993 Pituitary adenylate cyclase activating polypeptide (PACAP) can cross the vascular component of the blood-testis barrier in the mouse. Journal of Andrology 14 170-173.

Barberi M, Muciaccia B, Morelli MB, Stefanini M, Cecconi S \& Canipari R 2007 Expression localization and functional activity of pituitary adenylate cyclase-activating polypeptide, vasoactive intestinal polypeptide and their receptors in mouse ovary. Reproduction 134 281-292. (https://doi.org/10.1530/REP-07-0051)

Bardosi S, Bardosi A, Nagy ZS \& Reglodi D 2016 Expression of PACAP and PAC1 receptor in normal human thyroid gland and in thyroid papillary carcinoma. Journal of Molecular Neuroscience 60 171-178. (https://doi. org/10.1007/s12031-016-0823-7)

Barrionuevo F \& Scherer G 2010 SOX E genes: SOX9 and SOX8 in mammalian testis development. International Journal of Biochemistry and Cell Biology 42 433-436. (https://doi.org/10.1016/j.biocel.2009.07.015)

Barrionuevo FJ, Hurtado A, Kim GJ, Real FM, Bakkali M, Kopp JL, Sander M, Scherer G, Burgos M \& Jiménez R 2016 Sox9 and Sox8 protect the adult testis from male-to-female genetic reprogramming and complete degeneration. Elife 5 pii e15635. (https://doi.org/10.7554/ elife.15635)

Bobrovskaya L, Gelain DP, Gilligan C, Dickson PW \& Dunkley PR 2007 PACAP stimulates the sustained phosphorylation of tyrosine hydroxylase at serine 40. Cell Signaling 19 1141-1149. (https://doi.org/10.1016/j. cellsig.2006.12.006)

Brubel R, Kiss P, Vincze A, Varga A, Varnagy A, Bodis J, Mark L, Jambor E, Maasz G, Hashimoto H et al. 2012 Effects of pituitary adenylate cyclase activating polypeptide on human sperm motility. Journal of Molecular Neuroscience 48 623-630. (https://doi.org/10.1007/ s12031-012-9806-5)

Burton KA \& McKnight GS 2007 PKA, germ cells, and fertility. Physiology 22 40-46. (https://doi.org/10.1152/physiol.00034.2006)

Canipari R, Di Paolo V, Barberi M \& Cecconi S 2016 PACAP in the reproductive system. In Pituitary Adenylate Cyclase Activating Polypeptide - PACAP, pp 405-420. EdsD Reglodi \&A Tamas. Switzerland: Springer Nature Publishing. (https://doi.org/10.1007/9783-319-35135-3)

Counis R, Laverriere JN, Garrel-Lazayres G, Cohen-Tannoudji J, Larivière S, Bleux C \& Magre S 2007 What is the role of PACAP in gonadotrope function? Peptides 28 1797-1804. (https://doi. org/10.1016/j.peptides.2007.05.011)

Csaba Z, Csernus V \& Gerendai I 1997 Local effect of PACAP and VIP on testicular function in immature and adult rats. Peptides 18 1561-1567. (https://doi.org/10.1016/S0196-9781(97)00243-X)

Daniel PB \& Habener JF 2000 Pituitary adenylate cyclase activating polypeptide gene expression regulated by a testis-specific promoter in germ cells during spermatogenesis. Endocrinology 141 1218-1227. (https://doi.org/10.1210/endo.141.3.7347)

Daniel PB, Kieffer TJ, Leech CA \& Habener JF 2001 Novel alternatively spliced exon in the extracellular ligand-binding domain of the pituitary adenylate cyclase activating polypeptide (PACAP) type 1 receptor (PAC1 r) selectively increases ligand affinity and alters signal transduction 
coupling during spermatogenesis. Journal of Biological Chemistry 276 12938-12944. (https://doi.org/10.1074/jbc.M009941200)

Egri P, Fekete Cs, Dénes Á, Reglódi D, Hashimoto H, Fulop BD \& Gereben B 2016 Pituitary adenylate cyclase-activating polypeptide (PACAP) regulates the hypothalamo-pituitary-thyroid (HPT) axis via type 2 deiodinase in male mice. Endocrinology 157 2356-2366. (https://doi. org/10.1210/en.2016-1043)

El-Gehani F, Tena-Sempere M \& Huhtaniemi I 2000 Evidence that pituitary adenylate cyclase activating polypeptide is a potent regulator of fetal rat testicular steroidogenesis. Biology of Reproduction 63 1482-1489. (https://doi.org/10.1095/biolreprod63.5.1482)

Erdodi F, Toth B, Hirano K, Hirano M, Hartshorne DJ \& Gergely P 1995 Endothall thioanhydride inhibits protein phosphatases-1 and $-2 \mathrm{~A}$ in vivo. American Journal of Physiology 269 C1176-C1184.

Farkas J, Sandor B, Tamas A, Kiss P, Hashimoto H, Nagy AD, Fulop BD, Juhasz T, Manavalan S \& Reglodi D 2017 Early neurobehavioral development of mice lacking endogenous PACAP. Journal of Molecular Neuroscience 61 468-478. (https://doi.org/10.1007/s12031-0170887-z)

Georg I, Barrionuevo F, Wiech T \& Scherer G 2012 Sox9 and Sox8 are required for basal lamina integrity of testis cords and for suppression of FOXL2 during embryonic testis development in mice. Biology of Reproduction 87 99. (https://doi.org/10.1093/biolreprod/87.s1.99)

Gozes I, Perl O, Zamostiano R, Rubinraut S, Fridkin M, Shochat L \& Lewin LM 1998 Multiple actions of a hybrid PACAP antagonist: neuronal cell killing and inhibition of sperm motility. Annals of the New York Academy of Sciences 865 266-273. (https://doi. org/10.1111/j.1749-6632.1998.tb11187.x)

Gray SL, Cummings KJ, Jirik FR \& Sherwood NM 2001 Targeted disruption of the pituitary adenylate cyclase-activating polypeptide gene results in early postnatal death associated with dysfunction of lipid and carbohydrate metabolism. Molecular Endocrinology 15 1739-1747. (https://doi.org/10.1210/mend.15.10.0705)

Hannibal J \& Fahrenkrug J 1995 Expression of pituitary adenylate cyclase activating polypeptide (PACAP) gene by rat spermatogenic cells. Regulatory Peptides 55 111-115. (https://doi.org/10.1016/01670115(94)00110-J)

Harvey SJ, Perry J, Zheng K, Chen D, Sado Y, Jefferson B, Ninomiya Y, Jacobs R, Hudson BG \& Thorner PS 2006 Sequential expression of type IV collagen networks: testis as a model and relevance to spermatogenesis. American Journal of Pathology 168 1587-1597. (https://doi.org/10.2353/ ajpath.2006.050816)

Hashimoto H, Shintani N, Tanaka K, Mori W, Hirose M, Matsuda T, Sakaue M, Miyazaki J, Niwa H, Tashiro F et al. 2001 Altered psychomotor behaviors in mice lacking pituitary adenylate cyclaseactivating polypeptide (PACAP). PNAS 98 13355-13360. (https://doi. org/10.1073/pnas.231094498)

Hatano Y, Shima H, Haneji T, Miura AB, Sugimura T \& Nagao M 1993 Expression of PP2A B regulatory subunit beta isotype in rat testis. FEBS Letters 324 71-75. (https://doi.org/10.1016/0014-5793(93)81535-8)

Heindel JJ, Powell CJ, Paschall CS, Arimura A \& Culler MD 1992 A novel hypothalamic peptide, pituitary adenylate cyclase activating peptide, modulates Sertoli cell function in vitro. Biology of Reproduction 47 800-806. (https://doi.org/10.1095/biolreprod47.5.800)

Horvath G, Reglodi D, Brubel R, Halasz M, Barakonyi A, Tamas A, Fabian E, Opper B, Toth G, Cohen M et al. 2014 Investigation of the possible functions of PACAP in human trophoblast cells. Journal of Molecular Neuroscience 54 320-330. (https://doi.org/10.1007/s12031014-0337-0)

Horvath G, Nemeth J, Brubel R, Opper B, Koppan M, Tamas A, Szereday L \& Reglodi D 2016 Occurrence and functions of PACAP in the placenta. In Pituitary Adenylate Cyclase Activating Polypeptide - PACAP, pp 389-403. EdsD Reglodi \&A Tamas. Switzerland: Springer Nature Publishing.

Isaac ER \& Sherwood NM 2008 Pituitary adenylate cyclase-activating polypeptide (PACAP) is important for embryo implantation in mice. Molecular and Cellular Endocrinology 280 13-19. (https://doi. org/10.1016/j.mce.2007.09.003)

Jozsa R, Hollosy T, Tamas A, Toth G, Lengvari I \& Reglodi D 2005 Pituitary adenylate cyclase activating polypeptide plays a role in olfactory memory formation in chicken. Peptides 26 2344-2350. (https://doi. org/10.1016/j.peptides.2005.03.054)
Juhász T, Matta C, Katona É, Somogyi C, Takács R, Gergely P, Csernoch L, Panyi G, Tóth G, Reglódi D et al. 2014a Pituitary adenylate cyclase activating polypeptide (PACAP) signalling exerts chondrogenesis promoting and protecting effects: implication of calcineurin as a downstream target. PLoS One 9 e91541.

Juhász T, Matta C, Somogyi C, Katona É, Takács R, Soha RF, Szabó IA, Cserháti C, Sző́dy R, Karácsonyi Z et al. 2014b Mechanical loading stimulates chondrogenesis via the PKA/CREB-Sox9 and PP2A pathways in chicken micromass cultures. Cell Signalling 26 468-482. (https://doi. org/ 10.1016/j.cellsig.2013.12.001)

Kanasaki H, Oride A, Tselmeg M, Sukhbaatar U \& Kyo S 2016 Role of PACAP and its PACAP type I receptor in the central control of reproductive hormones. In Pituitary Adenylate Cyclase Activating Polypeptide PACAP, pp 375-387. EdsD Reglodi \&A Tamas. Switzerland: Springer Nature Publishing.

Koh PO, Noh HS, Kim YS, Cheon EW, Kim HJ, Kang SS, Cho GJ \& Choi WS 2003 Cellular localization of pituitary adenylate cyclase activating polypeptide in the rat testis. Molecules and Cells 15 271-276.

Koh PO, Won K \& Cho JH 2006 Ethanol decreases the expression of pituitary adenylate cyclase activating polypeptide in rat testes. Journal of Veterinary Medical Science 68 635-637. (https://doi.org/10.1292/ jvms.68.635)

Kononen J, Paavola M, Pentilla TL, Parvinen M \& Pelto-Huikko M 1994 Stagespecific expression of pituitary adenylate cyclase activating polypeptide (PACAP) mRNA in the rat seminiferous tubules. Endocrinology 135 2291-2294. (https://doi.org/10.1210/endo.135.5.7956953)

Koppan M, Varnagy A, Reglodi D, Brubel R, Nemeth J, Tamas A, Mark L \& Bodis J 2012 Correlation between oocyte number and follicular fluid concentration of pituitary adenylate cyclase-activating polypeptide (PACAP) in women after superovulation treatment. Journal of Molecular Neuroscience 48 617-622. (https://doi.org/10.1007/s12031-0129743-3)

Koves K 2016 Presence and role of PACAP in endocrine glands of mammals. In Pituitary Adenylate Cyclase Activating Polypeptide - PACAP, pp 161-178. EdsD Reglodi \&A Tamas. Switzerland: Springer Nature Publishing.

Koves K, Kántor O, Lakatos A, Szabo E, Kirilly E, Heinzlmann A \& Szabo F 2014 Advent and recent advances in research on the role of pituitary adenylate cyclase-activating polypeptide (PACAP) in the regulation of gonadotropic hormone secretion of female rats. Journal of Molecular Neuroscience $\mathbf{5 4}$ 494-511. (https://doi.org/10.1007/ s12031-014-0294-7)

Lacombe A, Lelievre V, Roselli CE, Salameh W, Lue YH, Lawson G, Muller JM, Waschek JA \& Vilain E 2006 Delayed testicular aging in pituitary adenylate cyclase-activating peptide (PACAP) null mice. PNAS 103 3793-3798. (https://doi.org/10.1073/pnas.0505827103)

Levallet G, Bonnamy PJ \& Levallet J 2013 Alteration of cell membrane proteoglycans impairs FSH receptor/Gs coupling and ERK activation through PP2A-dependent mechanisms in immature rat Sertoli cells. Biochimica and Biophysica Acta 1830 3466-3675. (https://doi. org/10.1016/j.bbagen.2013.02.027)

Li M \& Arimura A 2003 Neuropeptides of the pituitary adenylate cyclase activating polypeptide/vasoactive intestinal polypeptide/growth hormone/secretin family in testis. Endocrine 20 201-214. (https://doi. org/10.1385/ENDO:20:3:201)

Li M, Mbikay M \& Arimura A 2000 Pituitary adenylate cyclase activating polypeptide precursor is processed solely by prohormone convertase 4 in the gonads. Endocrinology 141 3723-3730. (https://doi.org/10.1210/ endo.141.10.7717)

Li M, Funahasi H, Mbikay M, Shioda S \& Arimura A 2004 Pituitary adenylate cyclase activating polypeptide-mediated intracrine signaling in the testicular germ cells. Endocrine 23 59-75. (https://doi.org/10.1385/ ENDO:23:1:59)

Lv CM, Cheng DL, Zhao W \& Zhu H 2011 Pituitary adenylate cyclase activating polypeptide mRNA expression in rat testis and epididymis during postnatal development and experimental cryptochidism. Molecular Medicine Reports 4 793-798.

Matsumoto S, Arakawa Y, Ohishi M, Yanaihara H, Iwanaga T \& Kurokawa N 2008 Suppressive action of pituitary adenylate cyclase activating polypeptide (PACAP) on proliferation of immature mouse Leydig cell line TM3 cells. Biomedical Research 29 321-330. (https://doi.org/10.2220/biomedres.29.321) 
McClive PJ \& Sinclair AH 2003 Type II and type IX collagen transcript isoforms are expressed during mouse testis development. Biology of Reproduction 68 1742-1747. (https://doi.org/10.1095/ biolreprod.102.008235)

Miyata A, Arimura A, Dahl RR, Minamino N, Uehara A, Jiang L, Culler MD \& Coy DH 1989 Isolation of a novel 38 residue-hypothalamic polypeptide which stimulates adenylate cyclase in pituitary cells. Biochemical and Biophysical Research Communications 164 567-574. (https://doi.org/10.1016/0006-291X(89)91757-9)

Mizushima H, Nakamura Y, Matsumoto H, Dohi K, Matsumoto K, Shioda S \& Banks WA 2001 The effect of cardiac arrest on the blood-testis barrier to albumin, tumor necrosis factor-alpha, pituitary adenylate cyclase activating polypeptide, sucrose, and verapamil in the mouse. Journal of Andrology 22 255-260.

Nakamura K, Nakamachi T, Endo K, Ito K, Machida T, Oka T, Hori M, Ishizaka K \& Shioda S 2014 Distribution of pituitary adenylate cyclaseactivating polypeptide (PACAP) in the human testis and in testicular germ cell tumors. Andrologia 46 465-471. (https://doi.org/10.1111/ and.12102)

Nemeth A, Szabadfi K, Fulop B, Reglodi D, Kiss P, Farkas J, Szalontai B, Gabriel R, Hashimoto H \& Tamas A 2014 Examination of calciumbinding protein expression in the inner ear of wild type, heterozygous and homozygous pituitary adenylate cyclase activating polypeptide (PACAP)-knockout mice in kanamycin-induced ototoxicity. Neurotoxicity Research 25 57-67. (https://doi.org/10.1007/s12640-013-9428-x)

Niu Z, Zheng L, Wu S, Mu H, Ma F, Song W, Zhu H, Wu J, He X \& Hua J 2015 Ras/ERK1/2 pathway regulates the self-renewal of dairy goat spermatogonia stem cells. Reproduction 149 445-52. (https://doi. org/10.1530/REP-14-0506)

Racz B, Gasz B, Borsiczky B, Gallyas F Jr, Tamas A, Jozsa R, Lubics A, Kiss P, Roth E, Ferencz A et al. 2007 Protective effects of pituitary adenylate cyclase activating polypeptide in endothelial cells against oxidative stress-induced apoptosis. General and Comparative Endocrinology 153 115-123. (https://doi.org/10.1016/j.ygcen.2006.12.006)

Reglodi D, Kiss P, Szabadfi K, Atlasz T, Gabriel R, Horvath G, Szakaly P, Sandor B, Lubics A, Laszlo E et al. 2012 PACAP is an endogenous protective factor - insights from PACAP deficient mice. Journal of Molecular Neuroscience 48 482-492. (https://doi.org/10.1007/s12031012-9762-0)

Rosati L, Prisco M, Coraggio F, Valiante S, Scudiero R, Laforgia V, Andreuccetti P \& Agnese M 2014 PACAP and PAC1 receptor in the reproductive cycle of male lizard Podarcis sicula. General and Comparative Endocrinology 205 102-108. (https://doi.org/10.1016/j. ygcen.2014.05.009)

Rossato M, Nogara A, Gottardello F, Bordon P \& Foresta C 1997 Pituitary adenylate cyclase activating polypeptide stimulates rat Leydig cell steroidogenesis through a novel transduction pathway. Endocrinology 138 3228-3235. (https://doi.org/10.1210/endo.138.8.5314)

Sandor B, Fintor K, Reglodi D, Fulop DB, Helyes Z, Szanto I, Nagy P, Hashimoto H \& Tamas A 2016 Structural and morphometric comparison of lower incisors in PACAP-deficient and wild-type mice. Journal of Molecular Neuroscience 59 300-308. (https://doi.org/10.1007/s12031016-0765-0)

Shakhova O, Cheng P, Mishra PJ, Zingg D, Schaefer SM, Debbache J, Häusel J, Matter C, Guo T, Davis S et al. 2015 Antagonistic crossregulation between Sox 9 and Sox10 controls an anti-tumorigenic program in melanoma. PLoS Genetics 11 e1004877. (https://doi. org/10.1371/journal.pgen.1004877)

Sherwood NM, Krueckl SL \& McRory JE 2000 The origin and function of the pituitary adenylate cyclase-activating polypeptide (PACAP)/glucagon superfamily. Endocrinological Review 21 619-670.
Sherwood NM, Adams BA, Isaac ER, Wu S \& Fradinger EA 2007 Knocked down and out: PACAP in development, reproduction and feeding. Peptides 28 1680-1687. (https://doi.org/10.1016/j.peptides.2007.03.008)

Shioda S, Legradi G, Leung WC, Nakajo S, Nakaya K \& Arimura A 1994 Localization of pituitary adenylate cyclase activating polypeptide and its messenger ribonucleic acid in the rat testis by light and electron microscopic immunocytochemistry and in situ hybridization. Endocrinology 135 818-825. (https://doi.org/10.1210/ endo.135.3.8070375)

Siu MK, Wong CH, Lee WM \& Cheng CY 2005 Sertoli-germ cell anchoring junction dynamics in the testis are regulated by an interplay of lipid and protein kinases. Journal of Biological Chemistry $28025029-25047$. (https://doi.org/10.1074/jbc.M501049200)

Tamas A, Javorhazy A, Reglodi D, Sarlos DP, Banyai D, Semjen D, Nemeth J, Lelesz B, Fulop BD \& Szanto Z 2016 Examination of PACAP-like immunoreactivitiy in urogenital tumor samples. Journal of Molecular Neuroscience 59 177-183. (https://doi.org/10.1007/s12031015-0652-0)

Tanii I, Aradate T, Matsuda K, Komiya A \& Fuse H 2011 PACAP-mediated sperm-cumulus cell interaction promotes fertilization. Reproduction 141 163-171. (https://doi.org/10.1530/REP-10-0201)

Vaudry D, Falluel-Morel A, Bourgault A, Basille M, Burel D, Wurtz O, Fournier A, Chow BK, Hashimoto H, Galas L et al. 2009 Pituitary adenylate cyclase activating polypeptide and its receptors: 20 years after the discovery. Pharmacological Reviews 61 283-357. (https://doi. org/10.1124/pr.109.001370)

West AP, McKinnell C, Sharpe RM \& Saunders PT 1995 Pituitary adenylate cyclase activating polypeptide can regulate testicular germ cell protein synthesis in vivo. Journal of Endocrinology 144 215-223. (https://doi. org/10.1677/joe.0.1440215)

Wilson RJ \& Cumming KJ 2008 Pituitary adenylate cyclase-activating polypeptide is vital for neonatal survival and the neuronal control of breathing. Respiratory Physiology and Neurobiology 164 168-178. (https://doi.org/ 10.1016/j.resp.2008.06.003)

Wong CH \& Cheng CY 2005 Mitogen-activated protein kinases, adherens junction dynamics, and spermatogenesis: a review of recent data. Developmental Biology 286 1-15. (https://doi.org/10.1016/j. ydbio.2005.08.001)

Yanaihara H, Vigh S, Kozicz T, Somogyvari-Vigh A \& Arimura A 1998 Immunohistochemical demonstration of the intracellular localization of pituitary adenylate cyclase activating polypeptide-like immunoreactivity in the rat testis using stamp preparation. Regulatory Peptides 78 83-88. (https://doi.org/10.1016/S0167-0115(98)00125-6)

Zákány R, Szucs K, Bakó E, Felszeghy S, Czifra G, Bíró T, Módis L \& Gergely P 2002 Protein phosphatase 2A is involved in the regulation of protein kinase A signaling pathway during in vitrochondrogenesis. Experimental Cell Research 275 1-8.

Zákány R, Szíjgyártó Z, Matta C, Juhász T, Csortos C, Szucs K, Czifra G, Bíró T, Módis L \& Gergely P 2005 Hydrogen peroxide inhibits formation of cartilage in chicken micromass cultures and decreases the activity of calcineurin: implication of ERK1/2 and Sox9 pathways. Experimental Cell Research 305 190-199.

Received 31 July 2017

First decision 21 August 2017

Revised manuscript received 18 October 2017

Accepted 3 November 2017 